\title{
Demographic and Youth Bonus; Creative Economic Development Based on Local Culture
}

\author{
Biky Uthbek Mubarok ${ }^{1}$, Margaretha Hanita ${ }^{2}$, Syaiful Rohman ${ }^{3}$ \\ \{1 uthbek23@gmail.com, ${ }^{2}$ margaretha.hanita@gmail.com, ${ }^{3}$ syaifulrohman71@gmail.com $\}$ \\ ${ }^{1,2,3,4}$ School of Strategic and Global Studies, Universitas Indonesia, Indonesia
}

\begin{abstract}
At present, Indonesia is in a period known as the demographic bonus. This period offers both opportunities and challenges for Indonesia, whether it can utilize this demographic bonus as an engine to boost economic growth or just the opposite. This study aims to see and analyze youth awareness and response in Yogyakarta to the issue of bonus demography, especially their role in developing a creative economy based on local culture. The respondents of this study are productive age people, especially young people, engaged in the creative economy based on local culture, in this case, batik. Data collection methods in this study use structured interview methods supported by observations and relevant literature.
\end{abstract}

Keywords: Demographic Bonus, Youth, Creative Economy

\section{INTRODUCTION}

The Indonesian nation today faces a reality of the abundant number of people who are in productive age. The government has even begun to prepare tools to anticipate the adverse effects of the situation, one of which is by throwing issues related to empowering the productive age community to the general public. The condition commonly referred to as the demographic bonus has begun to occur since the last few years and is expected to reach its peak in 2029-2030.

Most people view this demographic bonus as a plus (surplus) for Indonesia because, with the abundant productive workforce, the opportunity for the country's economic growth is very wide open. However, on the other hand, the demographic bonus is also considered a threat if not supported with appropriate devices to take advantage of these conditions. The abundance of productive labour will genuinely be a surplus value for Indonesia when the absorption of productive age people into the world of work leads to economic empowerment. If what happens is the opposite, where the productive age community becomes a burden for the community and the country, then it is when the bad things feared from a demographic bonus become real. Some experts see the correlation between bonus demography and economic growth as a complex. To see the relationship between the two, the benchmarks used include some variables, including population size, income, inequality, social-economic conditions and population structure including the birthrate, fertility and mortality. Thus, to see the linkages between bonus demographics and economic growth in a country in detail requires a profound and measurable assessment. 
The challenge to make this demographic bonus as a surplus for Indonesia will still last for the next few years. The government and the community are also required to respond to this condition actively and creatively to realize the positive side of the demographic bonus. The government must be able to facilitate the community to be able to develop existing potentials. On the other hand, the community, especially young people, must have full awareness of this condition and then respond with real actions that are creative and support towards economic empowerment.

At this point, the creative economy can be one solution, especially during minimal employment. Especially, in order to welcome the fourth economic wave or better known as industry 4.0, the government and society are required to develop new patterns in carrying out the wheels of the creative economy by following the development of existing technology. The development of the creative economy becomes essential because of the high potential owned, especially the real, local cultural wisdom. The government in this case has also demonstrated its sensitivity to the potential and opportunities of the creative economy by forming a body that focuses on the development of the creative economy. Of course, the government effort will be unrequited if the people who are also the subject of creative economic actors do not respond to these demographic bonus issues.

Public awareness and response in addressing this bonus demographic issue, especially in the field of the creative economy are fundamental. Therefore, this paper attempts to analyze and present an overview of the awareness and role taken by the community with bonus demographic issues, especially those engaged in the creative economy based on local culture in the Yogyakarta area. Based on the statistical data and results of a survey issued by the creative economy in 2017, D.I. Yogyakarta contributed $1.26 \%$ of the total creative economic products exported by Indonesia. 2 As a province rich in cultural values, Yogyakarta has great potential and opportunities to increase production in the creative economy based on local culture. However, of course, the prerequisites must first be fulfilled, start from the awareness and ability to respond to the bonus demographic and creative economy issues being echoed by the government.

\section{RESEARCH METHODOLOGY}

This research is qualitative research using descriptive analysis, while the data collection in this study uses an interview method, both structured and unstructured with sources or respondents selected based on research needs (purposive sampling). As complementary data, the observations are carried out in the research area and supported by relevant literature in the form of books, journals, and other literature.

The steps are taken to come to the conclusions of this study consist of several stages. First, learning the preliminary study on the demographic and creative economy bonus from the results of previous studies. Second, collecting literature relevant to the research discussion. Third, doing interviews and observations to get research data. Fourth, reviewing and analyzing research data to conclude. Fifth, compiling reports on research results in the appropriate writing format.

\subsection{Demographic Bonus and Challenges for Youth}

Demographic Bonus is one of the changes in demographic dynamics that occurs due to the changes in population structure according to age. This demographic transition phenomenon 
occurs because of the reduced birth rate coupled with long-term mortality. This results in the population of productive age increasing significantly exceeding the number of unproductive age population, namely those who are less than 15 years of age and those who are over 65 years of age. The parameters used in assessing the bonus demographic phenomenon are dependency ratio or dependency ratio, that is, the ratio that describes the comparison between the number of non-productive age and productive age. A low ratio will have implications for the country's economy, which can be used as an opportunity to increase the productivity of a country. The less non-productive age borne by productive age will have an impact on better economic growth. Ideally, maximum economic growth occurs when the dependency ratio is at 50. This condition is also called a window of opportunity.

This bonus demographic phenomenon requires a challenge for the government and society, especially for those who are in the productive age range. The abundance of the productive age population can at first glance be seen in line with economic growth, thanks to the increased productivity. However, this is only an opportunity that can become real if all elements of society can take advantage of the demographic bonus momentum. This opportunity can also turn into a disaster; otherwise, if the population surplus in the productive age is not accompanied by an increase in productivity that can boost economic growth.

There are at least three theses concerning the relationship between the increase in the population of productive age and the economic growth of a nation. The first thesis is a thesis which rejects the relationship between increasing population and increasing economic growth. This thesis considers that increasing population will reduce economic growth. The second thesis is a supportive thesis, which optimistically assumes that increasing population can be combined to be a driver of rising economic growth. Whereas the third thesis looks at the variable of population growth with economic growth variables not related, both of which run independently. This shows that many possibilities can occur from the phenomenon of demographic bonus seen from the side of a country's economic movements. In the case of demographic bonus in Indonesia, these possibilities also have the opportunity to become real, but the opportunity to become a supporter of economic growth or worse the economic situation are two possibilities that overshadow Indonesia.

In addition to the government, society must also be aware of the two possibilities above. Young people classified in the population of productive age have their challenge. Indonesian history has recorded various essential roles carried out by youth since the period of struggle against invaders until the birth of reform. Youth always play a vital role in the long history of the Indonesian people. Therefore, they are also required to play the same role in responding to the demographic bonus phenomenon that occurs in Indonesia.

In Act No. 40 of 2009, it is explained that youth are Indonesian citizens aged 16 to 30 years who enter a critical period of growth and development. Besides, they certainly have a fresher fighting spirit, judging from the education side of the youth in this period also has a better level of education than the youth in previous periods. This emerges excellent expectations among the community about the strategic role that the youth will take in the phenomenon of bonus demography, which undoubtedly leads to their role to become an actor of national economic growth. This expectation is not excessive given the youth, in Law No. 40 of 2009 , stated that they have a responsibility in national development, one of them is to improve the competitiveness and economic independence of the nation

Based on the results of the National Socio-Economic Survey (Susenas) released by the National Statistics Agency (BPS) on Indonesian youth statistics in 2017, a total of 63.36 million people or $24.27 \%$ of the total population of Indonesia are the youth age group. With a total of almost a quarter of Indonesia's total population, the youth are an essential part of the 
nation's development process in a better direction. What is more, this large number of youths is supported by statistics that say almost no illiterate youth. This also proves that in terms of knowledge, the youth in this period is indeed better than the youth in previous periods. Consequently, with more numbers and better knowledge, the challenges for these young people are far more significant to play a role in the history of nation-building, one of which is to drive the economy.

Demographic bonus generally requires five conditions so that the abundant population of productive age can indeed be a bonus or benefit for the nation's economic growth. Two of the five conditions have direct linkages and influence on the youth in the context of taking a role in the national economy. Population quality is the first prerequisite so that the demographic dividend that occurs can be optimized to become a bonus for economic growth. Although in terms of health, the youth are at the peak of health both physically and psychologically, this is not enough to make the youth as an actor driving the economy. There need to be other components that can support youth participation in the economic field, including knowledge, skills and sensitivity to the developments around.

Also, although the knowledge or education of the youth in the current period has a better level, this does not necessarily serve as a reference for their success as actors of an economical drive. This is only a prerequisite to maximizing opportunities from the phenomenon of demographic bonus that occur. One does not even need to be a graduate to take part in driving the economy, for example being an entrepreneur, but with a better academic education background, means there will be many more opportunities open because of his broader insight into the opportunities that exist. Therefore, these young people also need to be encouraged to be more prepared and braver in taking a significant role in the economic field, such as being given adequate skills and encouraged to try to open businesses in the creative economy.

The second condition for the opportunity to optimize the demographic bonus phenomenon is the availability of quality employment. Considering that the demographic bonus that will occur as many as 167 million and even 192.08 million people who are in productive age, then this will necessitate an increase in the need for employment as well. When demands for employment needs are not met, the abundant population of productive age may only be a disaster, especially for the Indonesian economy. This can happen because those who are unemployed / not working will be a burden on the country's economy. Conversely, if they can be economically empowered, then at that time they can be considered as a real demographic bonus. Residents who work make themselves not a burden to other residents, economically independent, increase purchasing power and can set aside their money to save.11

In the case of the availability of employment, the government and the community must not merely depend on the formal sector to become a worker or employee. Mindset society and even higher education institutions that are still oriented to become civil servants, workers or employees are very important to be changed immediately. The number of companies or agencies that provide opportunities to work is not proportional to the number of workforces ready to use. Moreover, in the phenomenon of demographic bonus in Indonesia, newcomers who are productive-age residents who have just entered working age will certainly not compete with their predecessors. This situation could have led to the emergence of a massive wave of unemployment if the solution was not immediately thought out that gave no other choice but to provide employment. It can be imagined, if almost as much as $25 \%$ of the total Indonesian population of around 63.36 million people are not absorbed maximally in the world of work, how much unemployment will increase.

Relying on the formal sector to absorb so many labours ready to be empowered is not a wise choice. Therefore, the government and especially the youth as newcomers in the world of 
work must dare to create their opportunities by penetrating the world of the creative economy or as entrepreneurs. There is much evidence showing that economic and industrial progress in a country is driven by the emergence of new entrepreneurs or creators in the world of economics. This is the biggest challenge for the young people to realize because after all the young people today are expected to be able to become the driving force of the country's economy especially with their vast numbers in the era of Indonesia's demographic bonus. On the other hand, the economic growth of a country is always confronted with classic problems about the limitations of employment that can optimally absorb labor.12

With the courage of young people to create their opportunities through the creative economy or entrepreneurship, the classic problems of employment will gradually be overcome. It will also be able to reduce the unemployment rate, which has been increasing all this time and has even become a national problem. The government must guard the coming of the bonus demographic phenomenon by preparing skills, giving access and accommodating the young people to be better prepared to respond to the demographic bonus that occurs whereas people who are in the productive age, especially young people must be aware of this phenomenon and prepare themselves always to be able to adjust to the situation through repositioning or innovations.

\subsection{Creative Economy Based on Local Culture}

The Indonesian Central Statistics Agency (BPS) released statistical data stating that up to August 2017, Indonesia's total population is estimated to reach 262.41 million. Of this amount, $74 \%$ or around 192.08 million people are residents of productive age, and $24.27 \%$ of the total population of Indonesia or around 63.36 million people are productive age population who enter the youth age group, between 16- 30 years. In these statistics, BPS also released the number of open unemployed until August 2017 which reached 7.04 million people, increasing rapidly to around 35 thousand people compared to the period of February 2017.13 The number of open unemployment is not impossible to experience an increase in the year next year considering that Indonesia is currently on a demographic bonus trend that allows an increase in the number of people of productive age from year to year.

A large number of people in the productive age, as explained above, will not be able to be absorbed maximally if they only rely on the formal sector. This situation, if not immediately addressed, will cause an increase in unemployment and increase the employment problem of the Indonesian economy. The most feasible solution is to create courageous actors in the creative economy sector. This sector has been successfully applied in many developed countries and has been seriously worked on in Indonesia in recent years. Although it did not work optimally, this creative economy sector has been able to contribute $7.44 \%$ to the entire national economy in 2016.

The creative economy is the concept of sustainable development by creating a competitive economic climate and having renewable resources reserves obtained through the exploitation of an unlimited amount of creative capital, namely ideas, talents and creativity. Creative Economy is a concept in a new economic era that intensifies information and creativity by relying on ideas and knowledge from human resources as the main production factors. This concept is usually supported by the existence of a creative industry that becomes its embodiment. The creative economy and creative industries are other names for efforts to increase the protection of Intellectual Property Rights (IPR).

To support the sustainability of this creative economy sector, a strong foundation is needed in the form of Indonesian human resources who are ready and capable. All elements of the 
country, including the government and society, must be able to prepare the foundation with a wide range of knowledge and skills. Creative Human Resources (HR) who can collaborate and orchestrate, describe a context, adapt to new patterns and reliably create local content is a mandatory requirement for anyone who wants to plunge into this sector.

Although it is not new, creative human resources still face many obstacles in developing creative economic sector in Indonesia, the obstacles that still need to be overcome include; 1) creative artistic-based human resources still do not understand the context of creativity in the creative industry era as a whole so that society sees the art world as an exclusive world; 2) creative human resources based on non-artistic (science and technology) are too microscopic in seeing their professionalism so that they are sometimes too mechanistic in thinking which results in less innovative; 3) Creative human resources both artistic and non-artistic are lacking the means to experiment and express so that their work is still less creative and less innovative. These constraints need to be overcome in terms of human resources, as well as those which support the development of other creative economies.

Creative Human Resources (HR) are human resources who struggle and benefit economically from their activities. According to Richard Florida, as quoted by Mulyono, creative human resources include people who pursue professions as scientists, engineers, architects, designers, educators, artists, musicians, entertainers and even workers from the management sector whose work relies on thinking in problem-solving and decision making. Meanwhile, based on the 2015-1019 Creative Economy Agency Strategic Plan, creative economy products are classified into 16 subsectors namely architecture, interior design, visual communication design, product design, film-animation-video, photography, craft, culinary, music, fashion, application and game developer, publishing, advertising, television and radio, performing arts and fine arts. All these sub-sectors are creative sectors that support the country's economy outside the oil and gas and non-oil and gas sectors and become the focus of development by the Republic of Indonesia's Creative Economy Agency. This creative sector contributes $7.44 \%$ to the total national economy, and in 2016 the creative economy GDP grew by $4.95 \%$.

Of the 16 creative economy sub-sectors, supported by technological advances, the four sub-sectors experienced rapid growth, namely visual communication design, music, video animation and architecture. This can be seen from the many emerging new creators in the field. On the other hand, there are three sub-sectors of the creative economy that make the most significant contribution to national GDP, namely culinary by $41.40 \%$, fashion by $18.01 \%$ and craft by $15.40 \%$. In addition to be the most significant contributor to national GDP, these three creative sub-sectors also absorb the most labour. This fact shows a great opportunity from the creative economy sector to reduce the problem of unemployment, especially in responding to the phenomenon of demographic bonus.

In addition to being oriented towards technology and information progress, the creative economy can also be developed based on local cultural wisdom. Local wisdom is a cultural product of the past that was formed as cultural excellence of the local community as well as geographical conditions in the broad sense that should be continuously maintained and preserved. The combination of the two, between the wisdom of local culture and advances in technology and information, has the opportunity to produce a product that, besides remaining oriented to the treasures of local wisdom, also follows the trend of technological progress. This can be seen as one of them in fashion products with batik motifs. By looking at the contribution of the fashion sector, which is quite significant to national GDP, the development of a creative economy based on local wisdom such as batik has considerable opportunities. 
Batik is a genuine Indonesian cultural product that has been rooted in Indonesian cultural traditions for many years. The word batik refers to a fabric with a pattern produced by wax which is applied to the fabric so that it retains the entry of colouring material. The process of making batik was initially an exceptional process through deep immersion so that generally the batik produced had profound meaning and purpose. Along with the times, innovation and modification of batik motifs experienced significant development, especially to adjust to the ongoing trend.

As part of a long-rooted cultural heritage, batik has become a product of local wisdom that is still in high demand by the public. Especially with various innovations in the fashion world that make batik as a primary material, fashion trends with batik motifs are very easy to find today. This can also be seen from the percentage of fashion contributions as one of the creative economic sectors that occupy the top three contributing to GDP growth. Also, batik has been recognized as a product of Indonesian cultural heritage (Indonesian Cultural Heritage) by the world. The United Nations Educational, Scientific and Cultural Organization or UNESCO (United Nations Educational, Scientific and Cultural Organization) has designated batik as a humanitarian heritage for oral and non-cultural cultures (Masterpieces of the Oral and the Intangible Heritage of Humanity) on October 2, 2009.25 This further affirms the authenticity of batik as a product of local wisdom from Indonesia in the eyes of the world, and therefore making batik as a reference for the development of the creative economy, especially in the fashion sector is part of the preservation of Indonesia's cultural heritage, besides of course also has high economic value.

\subsection{Strategies and Patterns of Creative Economy Development Based on Local Culture in Yogyakarta}

Entering the demographic dividend era, which in Indonesia is called the demographic bonus, various sectors, that support the country's economy, experience a shift in approach. If economic actors in Indonesia still rely on conventional approaches, then it is likely that the existence of their businesses will experience stagnation or even setbacks, which will lead to business death. Coupled with technological advancements in various aspects that drive the industrial world into a new era, industrial revolution 4.0, the challenge of simply maintaining business existence is very heavy. Not to mention the increasing population of productive age which has a significant chance to increase the number of unemployed people, Indonesia is haunted by the shadow of economic decline if the combination of industrial revolution 4.0 and the abundant population of productive age is not addressed appropriately.

One alternative solution as discussed above is through the development of the creative economy sector. By capitalizing on unlimited resources in the form of ideas and knowledge, this creative economy sector has the opportunity to become a booster for the nation's economic growth. There are so many sub-sectors that can be developed from the creative sector, one of which is based on the treasures of local wisdom in Indonesia, namely batik.

As a country that passes down batik as a world-recognized cultural heritage, Indonesia has many batik centres that are scattered throughout the Indonesian territory with various shades and distinctions of each. The condition of batik business in Indonesia has also experienced a lot of dynamics from year to year both developments and setbacks from various aspects, but until now the existence of batik business is still maintained and developed. Even with various innovations that have emerged in the world of fashion, batik business has experienced quite encouraging developments. This certainly indicates the awareness and sensitivity of the 
development and dynamics in the world of batik business that requires the use of new patterns and strategies to maintain the existence and realize business identity.

From various regions that become centres of batik in Indonesia, Yogyakarta is one of the centres of batik that has a unique and distinctive batik identity. Yogyakarta has also been designated a World Batik City by the World Craft Council. This shows that Yogyakarta has excellent potential from the characteristics and authenticity of batik owned. The World Craft Council or the WCC certainly does not simply define Yogyakarta as the world batik city. There are some specific criteria into consideration in the determination include;

1. Authenticity (Historical Value); shows that philosophically Yogyakarta has a close connection with the meaning of history with the art of batik.

2. Originality (Cultural Value); shows that Yogyakarta has a specific and original cultural identity, which includes meaningful motives or variety, methods of making and using them for special events.

3. Preservation (Transgeneration Value); shows that in Yogyakarta, there are efforts to preserve batik crafts as a cultural heritage from time to time which includes special education institutions.

4. Marketability (Economic Value), or in other words, the activities of batik craft that run in Yogyakarta have links and influences on the industrial chain.

5. Eco-Friendly (Green Value); shows the existence of conservation efforts and the development of traditions that are directed at the use of environmentally friendly technologies.

6. Internationality (Global Value); shows that batik originating from Yogyakarta has a significant reputation in the eyes of the international community.

7. Sustainability (Consistency Value); shows that there is an inclusive regeneration process of batik craftsmen from what was previously exclusive, especially for courtiers.

As a city of world batik, Yogyakarta can be called as a "warehouse" of various types of batik. However, it must also be admitted that the types and motifs of batik circulating in Yogyakarta are also filled with batik motifs from various surrounding areas such as Solo and Pekalongan. Technological developments have contributed to the world of batik in Yogyakarta with the emergence of the type of batik "stamp" and batik printing, although both are considered by many to be not included in the criteria of batik. Some of these factors positively influence the existence and development of Yogyakarta batik. The challenge to maintain the characteristics and identity of Yogyakarta batik is getting bigger. Therefore, strategies and innovative breakthroughs are needed in order to maintain the sustainability and branding of Yogyakarta batik in the eyes of consumers and the world.

The demographic bonus phenomenon experienced by Indonesia has its contribution and influence on the dynamics of crafts and local culture such as batik, especially in Yogyakarta. The population entering the productive age, which is dominated by the younger generation has the capital to give colour in the process of developing batik craft in Indonesia. By capitalizing on superior knowledge and mastery of technology, this young generation has the opportunity to become a separate threat for batik entrepreneurs who are already running. For young people who have been involved in batik business since the beginning, their potential is undoubtedly expected to be able to boost the world of batik into a better creative economy sector. Through them, the cultural wealth possessed by Indonesia is expected to be able to be harmonized with the development and advancement of information technology in the frame of a superior creative economy. 
Ideally, entering this era of demographic bonuses, businesspeople - including batik businesses - must be sensitive to the increasing population of productive age who can shift their position at any time. However, in reality, not all batik entrepreneurs - which cover the production sector and the marketing sector - in Yogyakarta are aware of the phenomenon of demographic bonuses and challenges. This condition is not a matter that is vital for the continuity of the batik business they are engaged in, but awareness of the emergence of the phenomenon of demographic bonuses and the possibilities that are born from them can lead to responsiveness to developments that occur. The results of field observations also show that batik entrepreneurs, both in the production sector and in the marketing sector, who are aware of this demographic bonus phenomenon have varied patterns and strategies and measurable steps in the context of developing their businesses. Thus, these batik entrepreneurs, besides remaining able to maintain the existence of their businesses firmly, also have the characteristics and product identity they possess. This is certainly different from batik entrepreneurs who do not have anticipatory steps towards development, including the phenomenon of demographic bonuses that are currently and will last for the next few years.

As one example is the strategy implemented by the CEO of Sogan Batik. Seeing the development of batik production methods that are increasingly sophisticated by utilizing technological advances such as stamped batik or printing batik, the existence of written batik that still uses old production methods can be easily shifted. This is because in the process, making batik with the old method requires a longer time and patience, so the products produced are also limited, unlike the stamp or printing method that can be quickly produced in large quantities. Also, the abundance of the new workforce, which of course some of them will fill the arena of the world of batik presents its challenges for established batik businesses. Moreover, the new workforce is ensured to have mastery of skills that are more capable in the field of technology with various kinds of derivatives. This has great potential to create new dynamics and even disrupt the stability that has been arranged and has been running for a long time.

Seeing these challenges, the batik businessman who started his business in 2002 turned his brain so that the hand made products produced were still an option and the development of sophisticated tools did not displace his business house. He still maintains the process of making batik with the old method because according to him, it is one of the identities and characteristics of the original batik. To minimize competition that is so tight and to bring out the identity and character of batik that he produces, every product issued is always accompanied by a separate explanation. In this explanation, a separate history and philosophy are described, which describes the uniqueness of the batik products that he produces. Batik patterns or motifs used retain traditional batik motifs such as kawung motifs, machete motifs and others with a touch of innovation The responsive step towards the development of technology in the business world of batik as a treasure of local wisdom, apart from being an effort to keep the batik business going on, is also a form of preservation of local wisdom and authenticity of batik.

Specific strategies implemented by batik business actors to maintain the stability and development of the batik business involved, one of which is described above, is generally only owned by business actors who are aware of the developments and challenges brought. The batik entrepreneurs who are not aware and do not follow updated issues such as the phenomenon of bonus demography or revitalization of the creative economy usually do not have a specific strategy in order to deal with the wave of change. From the interview data, businesspeople who do not understand these issues will only use the most commonly used development patterns, such as the use of social media to support the marketing of their 
products. The rest, there are very few specific strategies that are used because of the lack of awareness of the challenges in the era of bonus demography and creative economy.

In general, the pattern or strategy used by the creative entrepreneurs in the batik sector in Yogyakarta can be explained as follows:

1. Use of social media. This strategy is the most common strategy used to support product marketing. The most widely used application is Instagram. Also, others use other applications such as Facebook, Twitter or Patch.

2. You are participating in exhibitions held by the government or private institutions. This strategy is generally done to introduce batik products through a special event to capture consumers.

3. Conduct a batik training program. This program is held in a paid pattern or in order to recruit workers to increase production.

4. Batik tour. This step is done by opening a production house as a tourist destination that displays the process of making batik, batik products and facilities to try batik.

5. Batik design innovation. This step is usually done by giving a touch of innovation to the batik motif or emphasizing the style of fashion with batik patterns. Generally, the designs chosen are tailored to the targeted market share, such as socialites and others.

6. Branding products. One example is to include stories, histories or philosophical meanings contained in related batik products.

A more specific step or strategy is certainly also owned by batik entrepreneurs, which is undoubtedly also adjusted to their respective conditions. However, in general, batik entrepreneurs who are aware of current issues along with their potential and availability for the business being carried out have clearer anticipatory steps. This fact should get special attention so that businesspeople in the existing batik sector can survive and develop their business in a more advanced direction. Alignment between the treasures of local wisdom and technological advancement can be started from an awareness of the current situation with the support of unlimited resources in the form of creative knowledge, ideas and ideas.

\section{CONCLUSION}

The demographic bonus phenomenon that occurs in Indonesia continues to get attention from various circles, as evidenced by the many discussions related to the theme. The premise that demographic bonuses have the chance to become a disaster if it is not responded to by preparing quality human resources is the trigger for many discussions on the theme. The government, in various ways, has tried to anticipate the lousy potential that arises from the dividend, even the government hopes that this phenomenon can bring blessings to the Indonesian economy. The big challenge is in the hands of young people, especially those who have just entered a productive age. Can they optimize themselves and their ability to drive the progress of the country's economy, not vice versa as a burden on the country's economy? Youth awareness of this matter is essential, so they want to be actively involved in positive and productive things for the country's economy.

A creative economy which is a concept of sustainable development by relying on unlimited resources in the form of ideas, talents and creativity is one alternative solution to reduce the threat of unemployment waves the effects of the phenomenon of demographic bonuses. So far, the contribution of the creative economy sector to national GDP can be said to be quite significant and will continue to increase when viewed from the development trend. 
The momentum will have a positive impact if it can be appropriately used. Moreover, the creative economic subsector that can be worked on by the new workforce is quite varied. One of them is the fashion subsector, which ranks the top three in its contribution to national GDP. From this sub-sector, one that can be pursued in the form of batik craft that has been recognized worldwide as Indonesia's cultural heritage. By pursuing the field of batik, these batik entrepreneurs have two roles: economic contribution to themselves and at the same time contributing to preserving Indonesia's cultural heritage.

The dynamics of batik business that have occurred so far have shown intense competition, especially with the support of technological advances in both the production and marketing sectors. In the production sector, batik production methods are enlivened by the stamp method, and the printing method, which is the competitor for handmade batik in terms of quantity. In the marketing sector, social media is a new market for batik entrepreneurs to sell their wares. The new patterns in the batik business are an opportunity for the new workforce that is superior to mastering technology and giving challenges to businesspeople who are already running. Therefore, new strategies emerged in the batik business world to maintain existence and develop the business.

\section{ACKNOWLEDGEMENT}

This research based on grant scheme of PITTA (Publikasi International Terindeks untuk Tugas Akhir) 2018 or also known as Indexed International Publications for Final Projects toward Universitas Indonesia students. Thank you to Margaretha Hanita and Syaiful Rohman as my advisor.

\section{REFERENCE}

[1]. Ali, M. Amir P.,2008,Potret Pemuda Indonesia, Yogyakarta: Ombak.

[2]. Alwi,Tantowi, "Tujuh Kriteria Dewan Kerajinan Dunia dalam Menetapkan Yogya sebagai Kota Batik Dunia”, Tribun Jogja, 27 Oktober 2017.

[3]. Antariksa,Basuki, "Konsep Ekonomi Kreatif: Peluang dan Tantangan Dalam Pembangunan di Indonesia", diakses dari www.kemenpar.go.id

[4]. Badan Ekonomi Kreatif, "Data Statistik dan Hasil Survey Ekonomi Kreatif", Direktorat Riset dan Pengembangan Ekonomi Kreatif Deputi Riset Edukasi dan Pengembangan, 2017.

[5]. Badan Ekonomi Kreatif, "Rencana Strategis Badan Ekonomi Kreatif 2015-1019-pdf".

[6]. Badan Ekonomi Kreatif, "Data Statistik dan Hasil Survey Ekonomi Kreatif 2016".

[7]. Badan Ekonomi Kreatif dan Badan Pusat Statistik, Infografis Ringkasan data Statistik Ekonomi Kreatif Indonesia, diakses dari www.bekraf.go.id.

[8]. Badan Pusat Statistik,2018,Statistik Pemuda Indonesia 2017, Jakarta: BPS.

[9]. Badan Pusat Statistik, 2018,Keadaan Angkatan Kerja di Indonesia 2017, Jakarta: BPS.

[10]. David Bloom, David Canning dan Jaypee Sevilla,2003, The Democratic Dividend: A New Perspective on the Economic Consequences of Population Change, Santa Monica: RAND.

[11]. Galih,Bayu, "2 Oktober 2009, UNESCO Akui Batik Sebagai Warisan Dunia dari Indonesia”, Kompas, 2 Oktober 2017.

[12]. Iskandar dan Eny Kustiyah, "Batik Sebagai Identitas Kultural Bangsa Indonesia di Era Globalisasi”, GEMA, THN XXX/52/Agustus 2016-Januari 2017. 
[13]. Kartini Parmono, "Nilai Kearifan Lokal Dalam Batik Tradisional Kawung” Jurnal Filsafat. Vol. 23, Nomor 2, Agustus 2013.

[14]. Kementrian Komunikasi dan Informatika Republik Indonesia,2014,Siapa Mau Bonus Demografi? Peluang Demografi Indonesia, Jakarta: Kominfo.

[15]. Lee, Ronald, "The Demographic Transition: Three Centuries of Fundamental Change", Journal of Economic Perspectives 17 (4), 2003.

[16]. Mulyono, Mauled, 2010,Menggerakkan Ekonomi Kreatif: Antara Tuntutan dan Kebutuhan, Jakarta; Rajawali Press.

[17]. Sartini,2009,Mutiara Kearifan Lokal Nusantara, Yogyakarta: Kepel Press.

[18]. Sularso, Dkk.,2009,60 Tahun Gabungan Koperasi Batik Indonesia, Jakarta; Koperasi Batik Indonesia,

[19]. Undang-Undang No. 40 Tahun 2009 tentang Kepemudaan. 